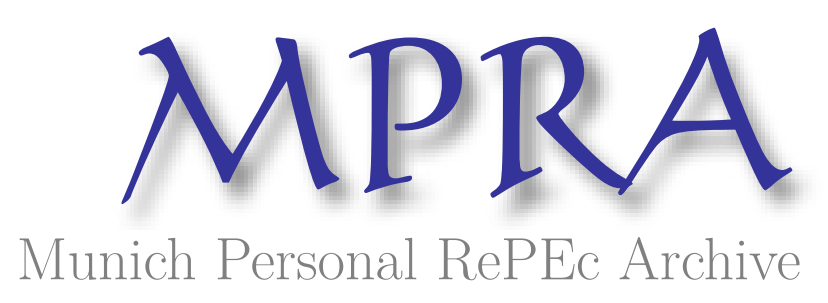

\title{
A conceptual model for the use of social media in companies
}

Nistor, Cristian

Alexandru Ioan Cuza University Faculty of Economics and Business Administration

4 January 2013

Online at https://mpra.ub.uni-muenchen.de/44224/

MPRA Paper No. 44224, posted 06 Feb 2013 09:00 UTC 


\title{
A conceptual model for the use of social media in companies
}

\author{
Phd. candidate Nistor George Cristian
}

\begin{abstract}
Social media is currently an evolving "wave" in online business marketing. Marketers are beginning to drive the use of social media as a component in their marketing strategy and campaigns to reach out to customers and fans. Within the subdisciplines of marketing that may use social media include promotions, marketing intelligence, sentiments research, public relations, marketing communications and product and customer management. This paper will try to find a conceptual model to examine people's behavior, model based on the the Theory of Reason Action (TRA) and the Technology Acceptance Model (TAM).
\end{abstract}

Keywords: Social media, Social networks, Social influence, Technology acceptance model, perceived ease of use, perceived usefulness.

\section{Introduction}

The technology acceptance model [11, Davis, 1989] is one of the most widely used models of IT adoption. According to TAM model, IT adoption is influenced by two erceptions: usefulness and ease-of-use. acceptance. Since social network characteristics are group-level characteristics and the technology acceptance model (TAM) is grounded on an individual level, there is a need for a mediating variable that links group-level characteristics to individual-level characteristics. However, TAM focuses on the individual psychological level of technology acceptance, with less attention for the social context such as social networks that surround the user [38, Sykes et al., 2009]. As such, from an academic and practice perspective, little is known about the influence of these networks on the technology acceptance of individuals.

Prior research already indicated that social networks can influence technology acceptance [13, Eckhardt et al., 2009]. They do so, since social networks contain "a specific set of linkages among a defined set of persons, with the additional property that the characteristics of these linkages as a whole may be used to interpret the social behavior of the persons involved" [20, Laumann et al., 1978]. In essence, TAM postulate that IT adoption is affected by prior use-related beliefs. TAM identified two such beliefs: perceived usefulness (PU) and perceived ease of use (PEOU) [41, Venkatesh, 2010]. Predicting the adoption and use of information technology has been a key interest since the early days of information systems research [7, Burton-Jones, 2005].

The main goal of technology acceptance theory is, to explore the factors that influence the adoption and diffusion of new technologies throughout a social system [5, Barnes, 2003]. Over the years, several independent theories for the acceptance as well as adoption of information technology have been developed. Most of these models apply to situations, in which individuals can voluntarily choose whether to adopt an innovation or not [15, Gallivan, 2001]. Perceived usefulness, perceived ease-of-use, and social influence appear to be promising variables for explaining behavior for the adoption of social media in different organization; however, more research is necessary to explicate the possible effect of social influence on perceived usefulness and perceived ease-of-use and how these variables may coinfluence the usage of social media technologies [12, Demei et al., 2006]. Another issue to be taken into account is that companies behaviors and attitudes may be influenced differently 
when interacting in social media with customers, competitors, suppliers which one of them holding different roles.

\section{Technology acceptance model}

In recent years, a number of influential models investigating intentions to adopt technology have emerged. These models have their origins in the disciplines of psychology, information systems and sociology [46, Venkatesh, Morris, Davis, \& Davis, 2003]. Among the best known of these is the Technology Acceptance Model (TAM) [11, Davis, Bagozzi, \& Warshaw, 1989]. Based on the Theory of Reasoned Action (TRA) [14, Fishbein \& Ajzen, 1975], the TAM has become well established as a robust, powerful and parsimonious model for predicting employee acceptance in the information technology domain [43, Venkatesh \& Davis, 2000].

TAM suggests that when users are presented with a new technology, different variables influence the decision whether and how they will use it. Two causal linkages influence this decision: perceived usefulness (PU) and perceived ease of use (PEOU) of the relevant technology [36, Stephan et al., 2010].

Perceived usefulness explains the user's perception to the extent that the technology will improve his/her work performance and perceived ease of use relates to the user's perception of the amount of effort required to utilize the system or the extent to which a user believes that using a particular technology will be effortless [11, Davis et al., 1989]. The model provides explanations of determinants of computer technology acceptance by tracing the impact of external factors on internal beliefs, intentions and attitudes [34, Rose et al., 2006].

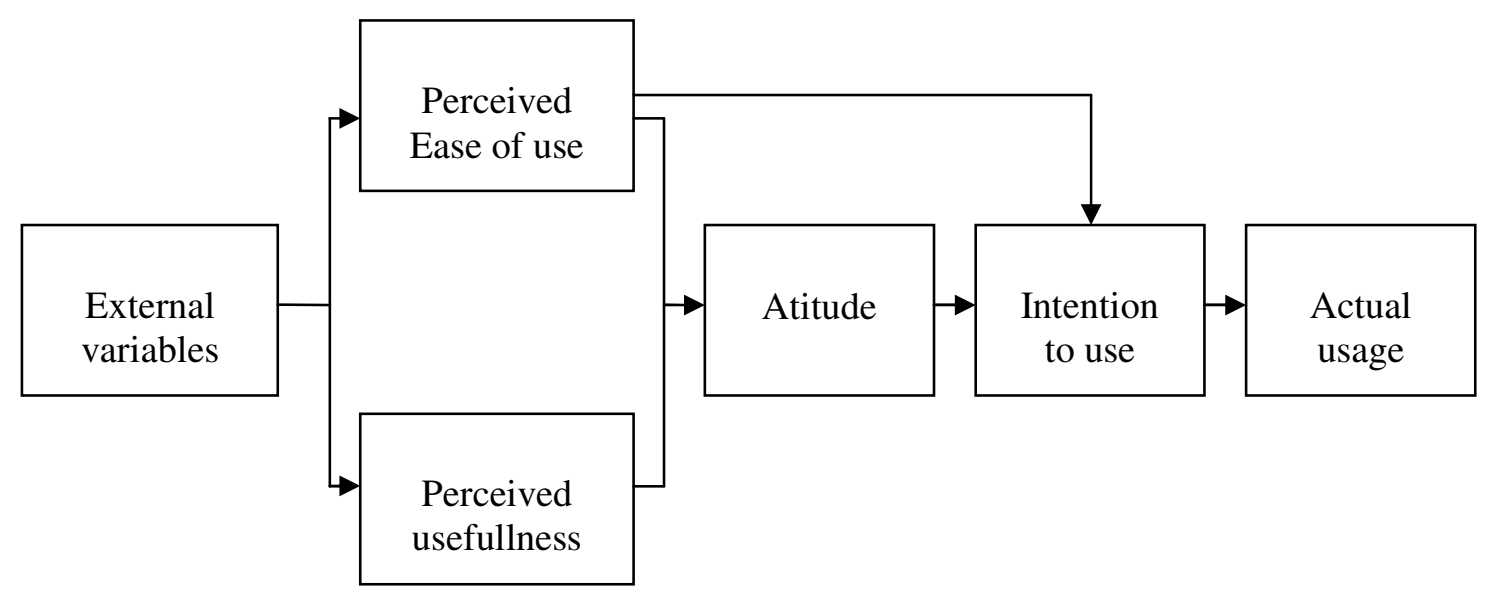

Fig. 2. Original Technology Acceptance Model

The parsimony of TAM combined with its predictive power make it easy to apply to different situations[41, Venkatesh, 2010]. However, while parsimony is TAM's strength, it is also the model's key limitation. TAM is predictive but its generality does not provide sufficient understanding from the standpoint of providing system designers with the information necessary to create user acceptance for new systems [28, Mathieson, 1991]. Specifically, it is important to emphasize that although perceived ease of use has been employed extensively in user acceptance research in general and TAM research in particular, very little has been done to understand the determinants of perceived ease of use [41, Venkatesh, 2010].

Davis' more recent work acknowledges this potential limitation: "While being very powerful in helping us predictaccept ance, one of the limitations of TAM is that it does not 
help understand and explain acceptance in ways that guide development beyond suggesting that system characteristics impact ease of use. This places a damper on our ability to meaningfully design interventions to foster acceptance. In order to be able to explain user acceptance and use, it is important to understand the antecedents of the key TAM constructs, perceived ease of use and usefulness" [44, Venkatesh and Davis, 1996]

The Technology Acceptance Model has been tested by numerous authors, including [1, Adams et al.,1992], [18, Hendrickson et al.,1993], [19, Igbaria et al.1997], [32, Riemenschneider et al.,2003], [37, Subramanian, 1994 ] [39, Szajna, 1994], [40, Taylor and Todd, 1995] or [9, Chin and Todd 1995]. In most of these studies, the TAM model was able to explain a reasonable amount of variance in the actual use of the technology [3, Alshare, 2004]. An up-to-date review of existing TAM studies and meta analyses can be found in [24, Ma and Liu, 2004] or [22, Legris et al., 2003]. Based on these studies, the original TAM model was extended by various authors to incorporate additional variables [33, Röcker, 2010], that may account for more variance in technology usage [3, Alshare et al., 2004].

The additional variables included perceived system performance [24, Ma and Liu, 2004], perceived user resources [27, Mathieson et al., 2001], prior experiences with similar technologies [2, Agarwal and Prasad, 1999][40, Taylor and Todd, 1995], age and education [2, Agarwal and Prasad, 1999] as well as personal innovativeness [2, Agarwal, and Prasad, 1998]. Further extensions of the Technology Acceptance Model were done by [9, Chin and Todd, 1995], [35, Segars and Grover 1993], [42, Venkatesh, 2000], [43, Venkatesh and Davis , 2000], [45, Venkatesh and Morris, 2000] as well as [16, Gefen and Straub, 1997].

\section{Perceived ease of use}

According to the definitions of [11, Davis et al., 1989], PEOU refers to "the degree, to which the [...] user expects the target system to be free of effort", Understanding the determinants of perceived ease of use is further underscored by the two mechanisms by which it influences intention: (1) perceived ease of use has a direct effect on intention, and an indirect effect on intention via perceived usefulness, and (2) it is an initial hurdle that users have to overcome for acceptance, adoption, and usage of a system.

\section{Perceived usefulness}

PU describes the individual's "subjective probability, that using a specific application system, will increase his or her jobperformance within an organizational context"[11, Davis, 1989]. Researchers have used the constructs of perceived usefulness, perceived ease-of-use, to explain technology usage/acceptance for a variety of information systems. [29, Miller et all., 2003] conducted a study in an online class delivered by interactive modules, which was developed using Authorware [...].They reported that perceived ease-of-use and perceived usefulness both have a significant and positive relationship with the amount of time students spent in the course[12, Demei et al., 2006].

\section{Social influence}

Social influence is defined as the perceived external pressure that individuals feel in the process of being informed about an innovation and decide to use it, and the degree in which an individual perceives that important others believe he or she should use the new system [14, Fishbein and Ajzen, 1975]. People tend to adjust their beliefs according to the group they are in. Individuals are also influenced by the majority: when a large portion of an individual's referent social group holds a particular attitude, it is likely that the individual will adopt it as well [4, Asch, 1951].

Previous studies have looked at the relationship between social ties and technology in areas such as exploitation of inter-organizational computer-mediated communication infrastructure [31, Pickering and King, 1995]; usefulness of electronic ties through broadcast 
messages [10, Constant et al., 1996]; and electronic media usage for information exchange [17, Haythornthwaite and Wellman, 1998]. However, so far a limited number of studies have been conducted on social influence and technology acceptance [21, Lee et al., 2003].

In the end I propose an conceptual model with the variables discused above as a result of the revised theory and findigs:

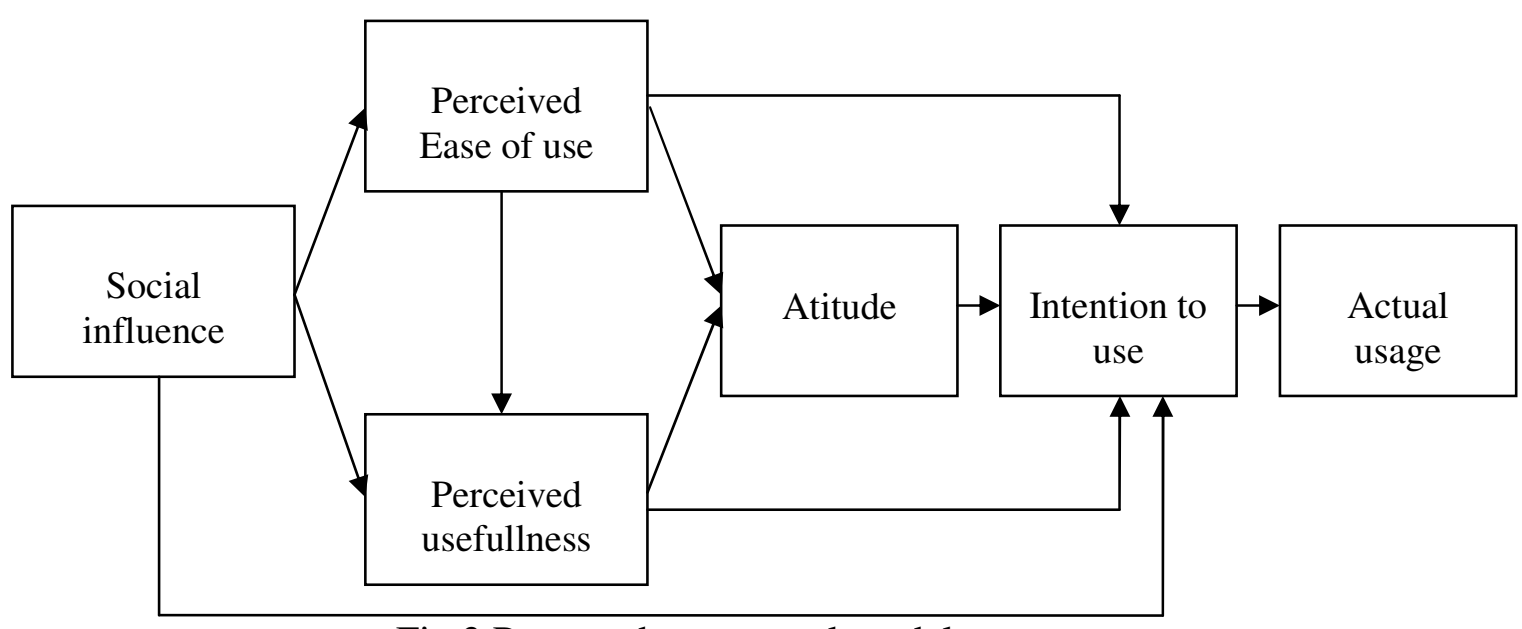

Fig.3 Proposed conceptual model

\section{Conclusions.}

In this research-in-progress study, I propose a conceptual model to examine the factors affecting attidude, intention to use and continuance intention of social media services from companies perspectives. Organizations should consider putting in place general computer training programs that target increasing computer awareness, enhancing computer selfefficacy, and reducing computer anxiety among employees that interact with customers in online. One of the areas that has not been exploited in practice is the potential for intrinsic motivation to enhance companies acceptance and usage. Much prior research [11, Davis et al., 1992], [25, Malone, 1981], [48, Webster and Martocchio, 1992], [47, Venkatesh and Speier, 1999] has found intrinsic motivation to be an important factor influencing acceptance and learning from individuals user perspective .

\section{Posible limitations}

Since the proposed model includes the fundamentals of the TAM, it is worthwhile to address some opinions about the model as well. There has been a streamlet that focused on its limitations and their arguments can be valid for this model as well [6, Benbasat and Barki, 2007]. [23, Lucas and Spitler, 2000] argue that the model is not applicable on the whole range of technology possibilities. They concluded that TAM might not work in the case of a complex technology.

Another important aspect is the cultural dimension. Cultural background of individuals influence the decision-making process and therefore, also the process of adoption and use of information systems [30, Myers and Tan, 2002]. [16, Gefen and Straub, 1997] investigated the gender differences and concluded that it affects the IT adoption process as well. Beside this, the conceptual model needs to to be empirical tested both on individuals and organizations especially here on comunity managers or comunity cordinators engaged in social media technologies. 


\section{References}

1. Adams, D. A., Nelson, R. R., Todd, P.A. (1992). Perceived Usefulness, Ease of Use, and Usage of Information Technology: A Replication. In: MIS Quarterly, Vol. 16, pp. 227 247.

2. Agarwal, R., Prasad, J. (1998). A Conceptual and Operational Definition of Personal Innovativeness in the Domain of Information Technology. In: Information Systems Research, Vol. 9, No. 2, pp. $204-215$.

3. Alshare, K., Grandon, E., Miller, D. (2004). Antecedents of Computer Technology Usage: Considerations of the Technology Acceptance Model in the Academic Environment. In: Journal of Computing Sciences in Colleges, Vol. 19, No. 4, pp. 164 180.

4. Asch, S.E. (1951). Effects of group pressure upon the modification and distortion of judgment. In: Guetzkow, H. (ed.). Groups, leadership, and men. Pittsburgh: Carnegie Press.

5. Barnes, S. J., Huff, S. L. (2003). Rising Sun: iMode and The Wireless Internet. In: Communications of the ACM, Vol. 46, No. 11, pp. 78 - 84.

6. Benbasat, I. and Barki, H. (2007). Quo vadis, TAM?. Journal of the Association for Information Systems, 8(4), 211-218.

7. Burton-Jones, A., Hubona, G. S. (2005). Individual Differences and Usage Behavior: Revisiting a Technology Acceptance Model Assumption. In: ACM SIGMIS Database, Vol. 36, No. 2, pp. $58-77$.

8. Carsten Röcker (2010), Why Traditional Technology Acceptance Models Won't Work for Future Information Technologies?, World Academy of Science, Engineering and Technology 652010

9. Chin, W. W., Todd, P. A. (1995). On the Use, Usefulness, and Ease of Use of Structural Equation Modeling in MIS Research: A Note of Caution. In: MIS Quarterly, Vol. 19, No. 2, pp. $237-246$.

10. Constant D., Sproull, L. and Kiesler, S. (1996). The kindness of strangers: The usefulness of electronic weak ties for technical advice. Organization Science, 7(2), 119137.

11. Davis, F. D., Bagozzi, R. P., \& Warshaw, P. R. (1989). User acceptance of computer technology: a comparison of two theoretical models. Management Science, 35(8), 9821003.

12. Demei, S., Laffey,J., Yimei, L.,Xinxin, H.,(2006) Social Influence for Perceived Usefulness and Ease-of-Use of Course Delivery Systems, Journal of Interactive Online Learning Volume 5, Number 3, Winter 2006

13. Eckhardt, A., Laumer, S. and Weitzel, T. (2009). Who influences whom? Analyzing workplace referents' social influence on IT adoption and non-adoption. Journal of Information Technology, 24, 11-24.

14. Fishbein, M., \& Ajzen, I. (1975). Belief, attitude, intention and behaviour: an introduction to theory and research. Reading, Massachusetts: Addison-Wesley.

15. Gallivan, M. J. (2001). Adoption, Diffusion, and Infusion of IT: Organizational Adoption and Assimilation of Complex Technological Innovations: Development and Application of a new Framework. In: ACM SIGMIS Database, Vol. 32, No. 3, pp. 51 85.

16. Gefen, D. and Straub, D.W. (1997). Gender differences in the perception and use of email: An extension to the Technology Acceptance Model. MIS Quarterly, 21(4), 389400 . 
17. Haythornthwaite, C. and Wellman, B. (1998). Work, friendship, and media use for information exchange in a networked organization. Journal of the American Society for Information Science and Technology, 49(12), 1101-1114.

18. Hendrickson, A. R., Massey, P. D., Cronan, T. P. (1993). On the Test- Retest Reliability of Perceived Usefulness and Perceived Ease of Use Scales. In: MIS Quarterly, Vol. 17, No. 2, pp. $227-230$.

19. Igbaria, M., Zinatelli, N., Cragg, P., Cavaye, A. L. M. (1997). Personal Computing Acceptance Factors in Small Firms: A Structural Equation Model. In: MIS Quarterly, Vol. 21, No. 3, pp. $279-305$.

20. Laumann, E.O., Galaskiewicz, J. and Marsden, P.V. (1978). Community structure as interorganizational linkages. Annual Review of Sociology, 4(1), 455-484.

21. Lee Y., Kozar, K.A. and Larsen, K.R.T. (2003). The technology acceptance model: past, present and future. Communications of the Association of Information Systems, 12(50), $752-780$.

22. Legris, P., Ingham, J., Collerette, P. (2003). Why Do People Use Information Technology? A Critical Review of the Technology Acceptance Model. In: Information and Management, Vol. 40, pp. 191 - 204.

23. Lucas, H.C. and Spitler, V.K. (2000). Implementation in a world of workstations and networks. Information and Management, 38(2), 119-128.

24. Ma, Q., Liu, L. (2004). The Technology Acceptance Model: A Meta- Analysis of Empirical Findings. In: Journal of End User Computing, Vol. 16, pp. 59 - 72.

25. Malone, T. W. (1981). Toward a theory of intrinsically motivating instruction. Cognitive Sci. 5(4) 333-369.

26. Mao, E., Palvia, P. (2006). Testing an Extended Model of IT Acceptance in the Chinese Cultural Context. In: ACM SIGMIS Database, Vol. 37, No. 2-3, pp. 20 - 32.

27. Mathieson, K. (1991). Predicting user intentions: Comparing the technology acceptance model with the theory of planned behavior. Inform. Systems Res. 2(3) 173-191.

28. Mathieson, K., Peacock, E., Chin, W. W. (2001). Extending the Technology Acceptance Model: The Influence of Perceived User Resources. In: The DATA BASE for Advances in Information Systems, Vol. 32, No. 3, pp. 86 - 112.

29. Miller, M., Rainer, R. K., \& Corley, J. K. (2003). Predictors of engagement and participation in an on-line Course. Online Journal of Distance Learning Administration, 6(1).

30. Myers, M.D. and Tan, F.B.M. (2002). Beyond models of national culture in information systems research. Journal of Global Information Management, 10(2), 24-32.

31. Pickering, J.M. and King, J.L. (1995). Hardwiring weak ties: Interorganizational computer-mediated communication, occupational communities, and organizational change. Organization Science, 6(4), 479-488.

32. Riemenschneider, C. K., Harrison, D. A., Mykytyn, P. P. (2003). Understanding IT Adoption Decisions in Small Business: Integrating Current Theories. In: Information \& Management, No. 40, pp. 269 - 285.

33. Röcker, C., (2010). Why Traditional Technology Acceptance Models Won't Work for Future Information Technologies? World Academy of Science, Engineering and Technology 652010

34. Rose, J., Fogarty,G., ( 2006)Determinants of perceived usefulness and perceived ease of use in the technology acceptance model: SENIOR CONSUMERS' ADOPTION OF SELF-SERVICE BANKING TECHNOLOGIES, Academy of World Business, Marketing \& Management Development Volume 2 No 10, July 2006 Conference Proceedings

35. Segars, A. H., Grover, V. (1993). Re-Examining Perceived Ease of Use and Usefulness: A Confirmatory Factor Analysis. In: MIS Quarterly, Vol. 18, No. 4, pp. 517 - 525. 
36. Stephan, K., Haverkamp, S.,Mahmood, F.,(2010) Social network influences on technology acceptance: A matter of tie strength, centrality and density,23rd Bled eConference eTrust: Implications for the Individual, Enterprises and Society June 20 23, 2010; Bled, Slovenia

37. Subramanian, G. H. (1994). A Replication of Perceived Usefulness and Perceived Ease of Use Measurement. In: Decision Science, Vol. 25, No. 5-6, pp. 863 - 874.

38. Sykes, T.A., Venkatesh, V. and Gosain, S. (2009). Model of acceptance with peer support: A social network perspective to understand individual-level system use. MIS Quarterly, 33(2), 371-393.

39. Szajna, B. (1994). Software Evaluation and Choice: Predictive Validation of the Technology Acceptance Instrument. In: MIS Quarterly, Vol. 18, No. 3, pp. 319 - 324.

40. Taylor, S., Todd, P. A. (1995). Understanding Information Technology Usage: A Test of Competing Models. In: Information Systems Research, Vol. 6, pp. 144 - 176.

41. Venkatesh Viswanath (2010),Determinants of Perceived Ease of Use: Integrating Control, Intrinsic Motivation, and Emotion into the Technology Acceptance Model, Information Systems Research Vol. 11, No. 4, December 2000

42. Venkatesh, V. (2000). Determinants of Perceived Ease of Use: Integrating Control, Intrinsic Motivation, and Emotion into the Technology Acceptance Model. In: Information Systems Research, Vol. 11, No. 4, pp. 342 - 365.

43. Venkatesh, V., \& Davis, F. D. (2000). A theoretical extension of the technology acceptance model: Four longitudinal field studies. Management Science, 46(2), 186204.

44. Venkatesh, V., F. D. Davis. 1996. A model of the antecedents of perceived ease of use: Development and test. Decision Sci. 27(3) 451-481.

45. Venkatesh, V., Morris, M. (2000). Why Don't Men Ever Stop to Ask for Directions? Gender, Social Influence, and their Role in Technology Acceptance and Usage Behavior. In: MIS Quarterly, Vol. 24, No. 1, pp. 115 - 139.

46. Venkatesh, V., Morris, M. G., Davis, G. B., \& Davis, F. D. (2003). User acceptance of information technology: towards a unified view. MIS Quarterly, 27(3), 425-478.

47. Venkatesh, V., Speier,C., (1999). Computer technology training in the workplace: A longitudinal investigation of the effect of the mood. Organ. Behavior and Human Decision Processes 79(1) 1-28.

48. Webster, J., J. J. Martocchio. (1992). Microcomputer playfulness: Development of a measure with workplace implications. MIS Quarterly,. 16(2) 201-226. 